\title{
Interaction of Meloidogyne incognita and Ralstonia solamacearum on brinjal (Solanum melongena L.)
}

\author{
S. PAVITHRA*, N.G. RAVICHANDRA AND G. NAGAMMA
}

Department of Plant Pathology, University of Agriculture Science, G.K.V.K., BENGALURU (KARNATAKA) INDIA

\section{ARITCLE INFO}

Received : 08.02 .2014

Revised : 21.08 .2014

Accepted : 03.09 .2014

\section{KEY WORDS :}

Brinjal, Meloidogyne incognita, Ralstonia solanacearum, Interaction

*Corresponding author:

Email: pavithra4157@gmail.com

\begin{abstract}
The combined pathogenic effects of Meloidogyne incognita and Ralstonia solanacearum on brinjal were greater than independent effects of either. $M$. incognita, 15 days prior to the inoculation of $R$. solanacearum led to maximum wilt incidence (100\%) followed by combined inoculation of both the pathogens simultaneously (75\%). Low wilt incidence was noticed in plants inoculated with bacterium alone (50\%).

How to view point the article : Pavithra, S. Ravichandra, N.G. and Nagamma, G. (2014). Interaction of Meloidogyne incognita and Ralstonia solanacearum on brinjal (Solanum melongena L.). J. Plant Protec., 7(2) : 411-414.
\end{abstract}

